\title{
Молодые и лишенные норм: идеологическое рекрутирование западных экстремистов Аль-Каидой
}

\author{
Терез Постел ${ }^{*}$
}

Взрывы на Бостонском марафоне 15 апреля 2013 года внесли страх и ужас в одно из старейших спортивных событий США и снова вернули терроризм на первый план американской народопсихологии. Мир наблюдал, как органы правопорядка запретили передвижение людей и транспорта на большой территории штата, чтобы найти сбежавшего террориста. После того как улеглась пыль преследования, стало ясно, что одно из самых ужасных террористических нападений на американской земле после 11 сентября 2001 совершил хорошо вписавшийся в среду, популярный, интеллигентный молодой человек, натурализованный гражданин США из семьи чеченских беженцев, под покровительством своего старшего брата.

Джохар Царнаев, студент колледжа Дармут Университета Массачусетса, был обнаружен четыре дня после взрывов в Уотертауне, Массачусетс, когда прятался в лодке, и впоследствии был арестован; с этого момента он не признает себя виновным ни по одному из выдвинутых против него обвинений. ${ }^{1}$ Брат Джохара, Тамерлан Царнаев, был сбит и убит Джохаром, когда они пытались убежать от органов правопорядка в ранние утренние часы 19 апреля 2013 года. ${ }^{2}$ Тамерлан был потенциальным героем американской истории успеха, который сбился с пути, не так хорошо приспособился, как его брат Джохар, которого его друзья и учителя ласково называли «Джахаром». Тамерлан был опытным боксером, совел с рельсов вскоре после того, как его мечта попасть в олимпийскую сборную США провалилась из-за того, что он не был гражданином США. ${ }^{3}$ Их родители подали на развод, их сестры переехали, и семейная жизнь этих двух мальчиков была разрушена. ${ }^{4}$ Вскоре после этого Джохар стал гражданином США, начал учиться в колледже,

\footnotetext{
Терез Постел уроженец района Куинс Нью-Йорка. У нее степень бакалавра, полученная в университете Дрью, и степень магистра, полученная в Миланской школе международных отношений, управления и городской политики. В настоящее время г-жа Постел работает в отделе менеджмента чрезвычайных ситуаций города Нью-Йорк. Взгляды, изложенные в этой работе, являются ее собственными и не отражают точку зрения ее работодателей.

1 Richard Oppel and Jess Bidgood, "Marathon Bombing Suspect, in First Court Appearance, Pleads Not Guilty," The New York Times (10 July 2013); доступно на www.nytimes.com/ 2013/07/11/us/in-court-for-first-time-boston-bombing-suspect-will-face-victims.html?_r=0.

2 Kevin Cullen, "New Details on Wild Shootout with Bomb Suspects in Watertown," Boston Globe (21 April 2013).

3 Lance Madden, "Boston Marathon Bombing Suspect No. 1 Tamerlan Tsarnaev Trained to Box for U.S.," Forbes (19 April 2013).

4 Josh Gerstein, "Boston Bombing Suspects' Parents Granted Divorce in 2011," Politico.com (22 April 2013); доступно на http://www.politico.com/blogs/under-the-radar/2013/04/bostonbombing-suspects-parents-granted-divorce-in-162313.html.
} 
начал баловаться наркотиками, ${ }^{5}$ тогда как Тамерлан не имел успеха ни в одном аспекте своей жизни.

Каким образом жизнь этих двух мужчин, начавшись так обещающе, пошла под откос? Этот вопрос мучил умы всех тех, кто пытался понять смысл этой террористической атаки и предотвратить другие. Ответ не так прост и не так очевиден, как его изображали. В прошлом году я закончила свою дипломную работу для получения магистерской степени о рекрутировании западных экстремистов Аль-Каидой. Я разделила схемы рекрутирования Аль-Каиды и сотрудничающих с ней организаций в три категории: структурные, институциональные и идеологические отношения. Тогда как структурные и институциональные связи между теми, кто хотят присоединиться или действовать в сотрудничестве с Аль-Каидой по всему миру часто весьма конкретны, идеологические отношения очень пористы и текучи. И именно по идеологическому каналу произошла радикализация братьев Царнаевых.

Очень важно понять идеологические влияния и отношения, которые толкают молодых людей к радикализации. Подобие в способах, которыми хейтерские группы, в том числе белые супремасисты, крайние правые экстремисты и такие фундаменталисткие религиозные группы как Аль-Каида, убеждают отдельных людей действовать насильственным способом от имени группы, очень поучительно для целей контррадикализации и контртерроризма.

Все подробности процесса радикализации Тамерлана Царнаева остаются пока неясными. Однако, последняя информация об этом случае показывает, что хотя начальный импульс для террористической атаки в Бостоне дала салафистская джихадистская литература, пропагандируемая Аль-Каидой, Тамерлан также погрузился и в другие экстремистские правые идеологии, характерные для Соединенных Штатов. ${ }^{6}$ Подобным извращенным образом Андерс Брейвик, тот, кто в июле 2011 совершил массовое убийство детей в летнем лагере, находящимся недалеко от Осло, подтвердил, что он восхищался идеологией, упорством и успехом Аль-Каиды, хотя он и был отъявленным белым супремасистом и исламофобом. Брейвик назвал Аль-Каиду «наиболее успешным революционным движением в мире» и заявил, что он надеется создать «Европейскую Аль-Каиду». ${ }^{7}$ Скрещиванием и подобием идей между этими крайними мировоззрениями больше нельзя пренебрегать. Контртеррористическая работа улучшится и расширится, если эксперты начнут лучше понимать характер лиц, которые склонны поддаваться влиянию идеологий, проповедуемых такими группами как Аль-Каида.

5 Chris Kirk and Heather Brady, "From Wrestling Captain to Terrorism Suspect: A Timeline of Dzhokhar Tsarnaev's Life,” Slate.com (23 April 2013); доступно на http://www.slate.com/ articles/news_and_politics/map_of_the_week/2013/04/timeline_boston_bombing_suspect_dzh okhar_tsarnaev_s_life.html.

6 Alan Cullison, "Boston Bombing Suspect Was Steeped in Conspiracies," The Wall Street Journal (6 August 2013); доступно на http://online.wsj.com/article/SB1000142412788732 3420604578649830782219440.html.

7 Richard Orange, “Al Qaeda Rejects Anders Behring Breivik Comparison,” The Telegraph (3 May 2012). 
Наименование этого журнала, Взаимосвязи, очень подходяще, поскольку я считаю, что идеологию, которую проповедует Аль-Каида и множество правых хейтерских групп в Соединенных Штатах, наиболее привлекательна для тех, кому не хватает устойчивых связей в их жизни. В этой статье сначала будет показано, как экстремистская идеология крайних правых групп и идеология Аль-Каиды попадают, находят отклик в одной и той же группе недовольных, исключенных из общества лиц, пытающихся найти смысл и чувство общности в своей жизни, используя похожие методы. Множество доказательств дает основание предположить, что как раз таким был и случай с Тамерланом Царнаевым. Значение этих связей для процесса радикализации позволяет мне оспаривать преобладающий ныне в сфере контртерроризма дискурс «одинокого волка». Далее в статье будет описано идеологическое рекрутирование для апокалиптического мировоззрения Аль-Каидой лиц, похожих на братьев Царнаевых, путем исследования случая Закарии Чессер, молодого американского мужчины, который в 2010 году неуспешно пытался поехать в Сомали, чтобы присоединиться к Аль-Каиде. Информация о братьях Царнаевых обширно представлена в майском номере 2013 года журнала Инспаер, ${ }^{8}$ англоязычного журнала Аль-Каиды, которая всего лишь за несколько месяцев до этого обеспечила их инструкциями и мотивами для их атаки. Понимание процесса радикализации для террористических групп любого вида может предотвратить потери человеческих жизней путем своевременного пресечения деятельности будущих террористов до того, как они будут в состоянии совершить какие бы то ни было насильственные действия.

\section{Вербовка радикалов: разные идеологии, играющие на одной и той же струне}

Существует мало теоретических исследований, пытающихся объяснить тактику вербовки Аль-Каиды. ${ }^{9}$ Может быть, эта нехватка информации о методах вербовки является результатом теневого, секретного характера группы. Но возможно, это есть так же результат отсутствия экспертов, занимающихся изучением того, как Аль-Каида вербует новых приверженцев. Вне литературы по схемам вербовки Аль-Каиды существует множество исследований, касающихся рекрутирования членов для внутренних для США хейтерских групп (групп ненависти). Аль-Каида и хейтерские группы используют схожую риторику, и их пропаганда направлена на одинаково недовольные лица.

Можно приблизиться к пониманию механизмов, с помощью которых Аль-Каида пытается вербовать членов, анализируя теорию, которая предназначена для объяснения методов вербовки, используемых правыми группами ненависти в Соединенных Штатах. Важно отметить, что средства пропаганды Аль-Каиды, подоб-

8 Inspire Magazine, Issue 11 (May 2013).

9 В этом эссе под наименованием Аль-Каида понимается любая группа или отдельные люди, которые принимают мировоззрение и цели Аль-Каиды, независимо от того связаны ли они формально с организацией, созданной Усамой бен Ладеном. 
ные журналу Инспаер, пытаются рекрутировать отдельных людей пассивно, путем индоктринации, так, как делают некоторые из внутренних групп ненависти. Похожим образом, рассматривая теории о природе терроризма в мире после 9/11, человек может понять идеологические темы, используемые для вербовки, на которых Аль-Каида основывает свой нарратив.

По мнению Южного юридического центра по вопросам бедности, в США существует более тысячи активных групп ненависти. ${ }^{10}$ Многие из этих групп создают внутренних террористов. До 9/11 наиболее успешной террористической атакой в Соединенных Штатах был взрыв федерального здания имени Альфреда П. Мурра в Оклахоме Сити в 1995 году. Тимоти Маквей, хотя и не был участником конкретной группы ненависти, был настроен активно антиправительственно и обвинялся в антисемитской риторике. ${ }^{11}$ Из-за существования этих групп ненависти Соединенные Штаты в большей степени, чем другие страны, знакомы с понятием внутреннего терроризма. Эти группы вербуют сторонников в основном тремя способами. Во-первых, их пропаганда направлена на людей, которые испытывают «аномию» или «напряжение» в своей жизни; лица, которые «фрустированы» своим положением в обществе, подвержены риску поддаться влиянию групп ненависти. ${ }^{12}$ Во-вторых, группы ненависти проповедуют, что их «статус-кво» находится под угрозой, и что люди должны присоединяться к этим группам, чтобы защитить положение в обществе своей этнической или религиозной группы. ${ }^{13} \mathrm{~B}$ третьих, многие из этих групп используют «апокалиптическую» риторику, чтобы вербовать сторонников. Многие люди считают, что их конкретное сообщество находится под угрозой и могут быть завербованы в группы ненависти, если они верят, что их борьба является делом жизни или волей божьей. ${ }^{14}$

В своем эссе «От белых мальчиков до взрослых террористов» Ренди Блазак приводит документальные свидетельства о рекрутировании сторонников неонацистскими скинхедами. Белые супремасисткие группы в Соединенных Штатах вербуют молодых людей для своего дела несколькими способами, которые схожи со способами, с помощью которых другие террористические группы набирают рекрутов. Блазак задокументировал, как эти группы скинхедов направляют свою агитацию на «конкретные популяции молодежи», используя идеологию, которая взывает к недовольным молодым людям. ${ }^{15}$ Блазак утверждает, что люди, которые

10 Southern Poverty Law Center, "Hate Мар," доступно на www.splcenter.org/get-informed/ hate-map.

11 “Timothy McVeigh,” CNN (29 March 2001); доступно на http://asia.cnn.com/2001/US/03/ 29/ profile.mcveigh/index.html.

12 Randy Blazak, "White Boys to Terrorist Men: Target Recruitment of Nazi Skinheads," American Behavioral Scientist 44:6 (2001): 982-1000.

13 Там же.

14 Там же.

15 Там же, 982. 
испытывают «аномию» или «отсутствие норм поведения» особенно уязвимы для вербовки со стороны скинхедов. ${ }^{16}$

Вербовщики для движений скинхедов, а так же и других движений ненависти на расовой основе в Соединенных Штатах, опираются на чувства «фрустрации, гнева и необходимости разрешить некоторую ощущаемую несправедливость». ${ }^{17}$ Молодые люди, которые страдают «чувством отсутствия корней или норм поведения» более склонны присоединяться к таким группам с целью найти для себя идентичность. ${ }^{18}$ Группы скинхедов создают нарратив об атаке на «культурное превосходство гетеросексуальных белых мужчин» с тем, чтобы вербовать молодых мужчин в районах, где есть ощущение угрозы статус-кво. ${ }^{19}$ Согласно Блазаку, в общности скинхедов и для нации в целом, существует тема о «кризисе культуры». ${ }^{20}$ Эта и подобные ей темы вызывают особенно сильный резонанс среди скинхедов - и, в совершенно другом контексте, среди симпатизантов Аль-Каиды. Такими темами являются: ненадежность «современной жизни», безудержное потребительство и «культ индивидуализма» в американском обществе. ${ }^{21}$ Страх «культа индивидуализма» наблюдается не только в западном обществе, но и во многих странах по всему свету, где люди обеспокоены тем, что глобализация приносит эти пороки и в их общества. Эти темы, наряду с напряжением от «отсутствия норм» в жизни молодежных групп риска, способствуют вербовке людей для террористических групп.

Возможно наиболее важный способ, это использование для вербовки людей божественного и апокалиптического нарратива. Группы ненависти в США заявляют, что они «делают Божье дело, чтобы спасти белую расу от исчезновения». ${ }^{22}$ Люди, завербованные группами скинхедов, захвачены желанием «возродить» гегемонию белых. Чувство принадлежности к общности формируется на основе веры, что они являются «немногими избранными», которые выиграют расовую войну, превратив Северо-Западные Соединенные Штаты в отечество арийских народов. ${ }^{23}$ Именно в этом желании вернуть мифическую эпоху превосходства белых видны наиболее яркие параллели с джихадистскими группами. ${ }^{24}$ Блазак отмечает, что скинхеды и движения белых супремасистов считают, что «расовая война» создаст в Соединенных Штатах родину только для белых. ${ }^{25}$ Этот нарратив применяется для рекрутирования лиц, которые испытывают «отсутствие норм» в своей жизни, и у которых мало других сильных привязанностей. Рекруты скинхе-

\footnotetext{
Там же, 986.

Там же.

Там же, 987.

Там же, 988.

Там же, 997.

1 Там же.

Там же, 983.

Там же, 994.

Там же.

5 Там же, 986.
} 
дов видят угрозу для своей идентичности белых мужчин в сегодняшнем обществе из-за ощущаемого изменения статус-кво.

Белые супремасисты обычно выделяют и взывают к людям, испытывающим отсутствие норм в своей жизни и обещают им восстановление их центральной позиции в обществе, в то же время, давая им все преимущества ощущения принадлежности к общности. Эти группы вербуют отчужденных людей и дают им ощущение общности на основе этнических и религиозных связей. Людям говорят, что они должны защищать это общество, и часто они убеждены, что это религиозная обязанность, или что их сообщество принимает участие в мифической или апокалиптической борьбе. Как будет видно ниже, Аль-Каида использует очень схожую идеологию с неонацисткими группами, и эксплуатирует те же самые связи с общностью и с религией.

Интересно отметить, что Би-Би-Си и Уолл-Стрит Джсонал недавно опубликовали доклады, что Тамерлан Царнаев, хотя и наверняка был мотивирован салафистским джихадизмом за несколько месяцев до бостонских взрывов, углубленно изучал идеологию крайних правых. ${ }^{26}$ Тамерлан часто заботился о старом человеке, живущим по соседству, Дональде Ларкинге, у которого его мать работала сиделкой. $^{27}$ Ларкинг дал Тамерлану копию Протоколов сионских мудрецов, любимого антисемитского писания Аль-Каиды и нацистских симпатизантов. ${ }^{28}$ Тамерлан предположительно подписался на несколько супремасистких бюллетеней, в том числе на Американскую свободную прессу (отмеченный Южным юридическим центром по вопросам бедности за его антисемитское содержание) и на Первую свободу, который ратует за «равные права для белых», тема, часто обсуждаемая в крайних правых экстремистских кругах, которые боятся изменений в обществе США. ${ }^{29}$ У Тамерлана так же был образец литературы о «изнасиловании наших прав на ношение оружии», типичный страх в дискурсе крайне правых экстремистов. ${ }^{30}$

Хотя эта крайне правая экстремистская литература, по-видимому, сыграла определенную роль в формировании образа мышления Тамерлана, вероятнее всего индоктринация в духе салафистского джихадизма была осуществлена во время его поездки в Дагестан и при предшествовавшем общении с его матерью, которая стала сверхрелигиозной вместе со своим сыном. ${ }^{31}$ На примере Тамерлана Царнаева можно увидеть, как конспиративные теории белых супремасистов, распро-

${ }^{26}$ Hilary Andersson, "Tamerlan Tsarnaev Had Right-Wing Extremist Literature," BBC News (5 August 2013); доступно на http://www.bbc.co.uk/news/world-us-canada-23541341.

27 Conor Simpson, "Meet the Man Who Supplied Tamerlan Tsarnaev with Right Wing Literature," The Atlantic Wire (6 August 2013); доступно на http://www.theatlanticwire.com/ national/2013/08/meet-man-who-gave-tamerlan-tsarnaev-his-right-wing-literature/68020/.

28 Cullison, "Boston Bombing Suspect Was Steeped in Conspiracies."

29 Там же.

30 Там же.

31 Alan Cullison, Paul Sonne, David George-Cosh, and Anton Troianovski, "Turn to Religion Split Suspects' Home,” The Wall Street Journal (22 April 2013); доступно на http://online.wsj.com/article/SB10001424127887324235304578437131250259170.html. 
страняемые крайними правыми в США, и салафистские джихадисткие взгляды могут оказать влияние на тех, кто чувствует существенное «напряжение» или «аномию» в своей жизни.

Салафистский джихадизм, известный в разговорном языке как «исламистский экстремизм», занял центральное место в западном дискурсе национальной безопасности после событий 11 сентября 2001 года. Поэтому большая часть литературы, посвященной изучению терроризма сегодня, говорит о слиянии между «старым» терроризмом и «новым» терроризмом. Эти дебаты важно учитывать при анализе Аль-Каиды и салафистского джихадизма. Многие ученые считают, что Аль-Каида и те, кто действуют от ее имени, являются предвестниками «новой» формы терроризма, и утверждают, что «старый» терроризм был политическим, осуществлялся при содействии государства и был менее насильственным, чем «новый» терроризм, связываемый с Аль-Каидой. Однако, это очень проблематическое отличие. Хотя Аль-Каида и связанные с ней террористические группы сегодня изменили свою тактику, но терроризм остается все тем же. Понимание, что Аль-Каида не является «новой» формой терроризма и она мотивирована политически - как и все предшествовавшие ей террористические группы - окажет влияние на то, как США проводят свои контртеррористические операции. Соединенные Штаты не сумеют противостоять, и даже сыграют на руку политической риторике Аль-Каиды, если ученые и дальше будут настаивать, что Аль-Каида является совершенно новой формой терроризма и поэтому у нее нет политических мотивов. Споры между учеными по поводу «старого» и «нового» терроризма являются интегральной частью дискуссии о стратегии идеологической вербовки рекрутов для Аль-Каиды.

Ученые Ричард Деветак, Стивен Саймон и Даниель Бенджамин считают, что Аль-Каида до, во время и после 9/11 представляет собой «новую» эпоху терроризма. ${ }^{32}$ Саймон и Бенджамин утверждают, что основной характеристикой старой формы терроризма являются его политические цели, которые в основном направлены на ослабление других сил в международной системе. ${ }^{33}$ Второй чертой «старого» терроризма, согласно этим ученым, является «преобладающе спонсированный государством» характер. ${ }^{34}$ В начале 1990 -х терроризм был продуктом национальных государств - конкретно «Ирана, Ирака, Кубы, Ливии, Северной Кореи и Китая» - которые спонсировали террористические группы и использовали их в качестве инструментов для осуществления национальных целей. ${ }^{35}$ Последней характеристикой, которая определяет старую форму терроризма, является его направленность на привлечение внимания, а не отнятие человеческих жизней. ${ }^{36}$ Бенджамин заявляет, что насилие «старого» терроризма было «тщательно

32 Richard Devetak, "Violence, Order, and Terror," in International Society and Its Critics, ed. Alex J. Bellamy (Oxford: Oxford Scholarship Online, 2005), 232.

33 Steven Simon and Daniel Benjamin, “America and New Terrorism," Survival 42:1 (2000): 65.

34 Там же, 59.

35 Там же, 61.

36 Там же, 65. 
направлено и пропорционально по масштабу» для того, чтобы избежать его неприятие людьми. Подобным образом Деветак соглашается, что насилие никогда не было «единственной тактикой» ранних террористических групп и утверждает, что им пользовались экономно. Эти ученые согласны, что все три характеристики изменились, чтобы создать предположительно новую форму терроризма, практикуемую Аль-Каидой и ее сподвижниками.

Эти ученые считают, что «новый» терроризм отказался от своего политического, покровительствуемого государством и менее насильственного характера в пользу новых характеристик. Согласно Саймону и Бенджамину, «новый» терроризм менее политизирован по своей природе и вместо этого имеет религиозную мотивацию. От этих террористов требуют вершить Божью волю, направленную на создание совершенного мира «космической эры». ${ }^{37}$ Далее, «новые» террористы демонстрируют пренебрежение к жизни невинных людей и стараются, чтобы их нападения имели более смертельный характер. Теологическое оправдание их действий, позволяет «новым» террористам, особенно Аль-Каиде, вести «войну без конца». ${ }^{38}$ Согласно Деветаку, поскольку эти новые террористические группы не выставляют никаких «являющихся предметом переговоров политических требований», прежде всего, они стараются устранить всякую оппозицию своим целям. ${ }^{39}$

И последнее, терроризм больше не рассматривается как покровительствуемый государством, а как функционирующий органически по схеме «ступица и спицы». ${ }^{40}$ Саймон и Бенджамин отмечают, что согласно их анализу Аль-Каида и другие «новые» террористические группы не рассчитывают на финансирование со стороны государства, а получают деньги от богатых доноров, персональных холдингов и пожертвований. ${ }^{41}$ Согласно этим ученым, такие ощущаемые изменения в финансировании, мотивации и тактике составляют собой существенное отличие «нового» терроризма от «старого». Однако, становится очевидным, что хотя, возможно, и произошли изменения среди акторов, но тактика террористических групп в основном остается все такой же. Лучшим объяснением для очевидных изменений является то, что как и все другие акторы с политическими целями, АльКаида изменяет свою стратегию по мере изменения ситуаций и контекста.

Что более важно, есть три фундаментальные ошибки, которые допускают эти ученые, когда проводят линию разделения между «новой» и «старой» версиями терроризма. Первая - это предположение, что выдвигаемые террористами религиозные цели не могут быть в то же время и политическими. Те, кто придерживаются религиозного учения Аль-Каиды, считают, что ислам сам по себе служит основой для нового «социального, политического и экономического порядка» но-

\footnotetext{
Там же, 66.

8 Там же, 68.

39 Devetak, "Violence, Order, and Terror," 240.

40 Simon and Benjamin, "America and New Terrorism," 68.

41 Там же, 71.
} 
вого общества, которое они пытаются создать. ${ }^{42}$ Аль-Каида считает ислам «революционной идеологией», которая объединяет мировое исламское сообщество. ${ }^{43}$ Религиозное основание, которое использует Аль-Каида и подобные ей группы для оправдания своих действий, не признается, чем оно на самом деле является: оправданием для политической «борьбы за господство в исламском мире». ${ }^{44}$ Это не «столкновение цивилизаций», как предполагают многие теоретики. Наоборот, Аль-Каида стремится к политическим целям, которые ее оппоненты отвергают и с которыми они воюют. Так же, если мы посмотрим на Аль-Каиду как на политическое движение, мы сможем утверждать, что проблема не в исламе, а в группе людей, которые искривляют ислам в политических целях.

Подобным образом теоретики считают, что «новый» терроризм отличается высокой степенью пренебрежения к человеческой жизни. Эта ошибочная концепция основывается на неправильном прочтении идеологии террористических групп. Аль-Каида и ее филиалы считают, что те, кто сотрудничает с господствующими силами на Ближнем Востоке, являются «вероотступниками» и поэтому виноватыми. Деветак и другие ученые заходят в опасные воды, применяя западные «номы» к этим группам и утверждая, что террористы отвергают «гуманистические ценности», ${ }^{45}$ что приводит к неверному анализу мотивов и целей этих групп. АльКаида и террористические группы не считают, что они действуют против «невинных», а что они борются с агрессорами. Чтобы анализировать возможности АльКаиды вербовать сторонников, надо понимать логику ее мышления.

И последнее, эти теоретики пропускают роль, которую все еще играют государства в террористической деятельности. Государственное спонсирование терроризма может быть уже настолько прямым, как некогда, но существуют солидные доказательства, что Пакистан, Иран и даже Саудовская Аравия продолжают поддерживать терроризм. ${ }^{46}$ Эти теоретики так же не понимают, что террористическим группам сегодня необходимо физическое пространство, откуда они могут действовать, и поэтому Афганистан, Пакистан, Йемен и Сомали играют интегральную роль в их операциях.$^{47}$ Террористические группы, может быть, и стали менее иерархическими, чем в прошлом, но это не означает, что государство не имеет никакого влияния или отношения к деятельности террористов.

42 John Turner, "From Cottage Industry to International Organisation: The Evolution of Salafi-Jihadism and the Emergence of the Al Qaeda Ideology," Terrorism and Political Violence 22 (2010): 542.

43 Там же, 549.

44 Там же, 542.

45 Devetak, "Violence, Order, and Terror," 240.

46 Daniel L. Byman, "The Changing Nature of State Sponsorship of Terrorism," Saban Center for Middle East Policy at the Brookings Institution, Analysis Paper No. 16 (May 2008), 8, 12, 21; доступно на www.brookings.edu/research/papers/2008/05/terrorism-byman.

47 Stuart Elden, "Territorial Integrity and the War on Terror," Environment and Planning 37:12 (2005): 2083-104. 
Царнаевы не являются примером покровительствуемого государством терроризма. Однако, радикализация Тамерлана произошла в течение шести месяцев его пребывания в Дагестане, российской провинции, в которой существует повстанческое движение против центрального правительства. Мотивы братьев все еще не выяснены полностью, но у них очевидно остались душевные шрамы от перемещения семьи в детстве и продолжающейся борьбы в их отечестве Чечня; их статус иммигрантов также способствовал усилению чувству отсутствия норм. Эти влияния вызывали у них ощущение напряжения и аномии, и способствовали тому, что они стали жертвами политических идей Аль-Каиды относительно защиты $y м m b l$ (мирового сообщества ислама). Эти идеи не являются источником для «новых» форм терроризма; на деле, увлеченность Тамерлана экстремистской литературой крайнего правого толка и салафистской джихадистской пропагандой на Ютюбе показывает, что эти как бы разные политические нарративы могут занимать общее место в уме молодых людей, которые чувствуют себя одинокими и изолированными.

При анализе схем вербовки Аль-Каиды в Соединенных Штатах и на Западе важно рассеять фальшивую дихотомию «старого» и «нового» терроризма. Непонимание политических целей, идеологии и того, что Аль-Каиде необходимо нестабильное государство, с территории которого можно действовать и продолжать вербовку членов, затрудняет наше понимание использования средств, с помощью которых происходит привлечение граждан западных государств в Аль-Каиду.

\section{Мысли Царнаевых: идеологическая вербовка Аль-Каидой и связанных с ней группировок}

Один из самых важных методов, с помощью которых Аль-Каида и ее филиалы радикализируют отдельных людей - это использование идеологических средств. Идеологию Аль-Каиды можно применять, чтобы создавать впечатление о «войне идей», которая может быть исключительно воздействующей на людей, испытывающих в своей жизни напряжение и аномию. Тамерлан Царнаев воевал со школой, никогда не сумел вписаться ни в какую социальную группу, стал свидетелем развода родителей и их возвращения в Россию и крушения своей олимпийской мечты боксировать за Америку. ${ }^{48}$ Эти переживания сделали его недовольным и одиноким. В фоторассказе Йоганнеса Хирна под названием «Боксировать за паспорт» Тамерлан говорит: «У меня нет ни одного американского друга, я не понимаю их». ${ }^{49}$ Идеология Аль-Каиды помогла ему приобрести чувство принадлежности к чему-нибудь большему, чем он сам: к умме.

48 Janeit Reitman, “Jahar's World,” Rolling Stone (17 July 2013), 9; доступно на www.rollingstone.com/culture/news/jahars-world-20130717.

49 David Weigel, "Tamerlan Tsarnaev, Dead Bombing Suspect: 'I Don't Have a Single American Friend'," Slate (19 April 2013); доступно на www.slate.com/blogs/weigel/2013/04/19/ tamerlan_tsarnaev_dead_bombing_suspect_i_don_t_have_a_single_american_friend.html. 
Его брат, Джохар, в колледже упорно работал, чтобы добиться тех же академических и социальных успехов, которыми он отличался в средней школе; и он начал интересоваться радикальным салафистским джихадизмом, чтобы укрепить свою связь с братом. ${ }^{50}$ В обвинительном акте Джохара утверждается, что он скачал несколько салафистских джихадистских проповедей и заявлений священнослужителей Абдулла Аззам и Анвар Ал-Авлаки, в которых шла речь о защите «мусульманских земель» от рук неверующих. Это согласуется с другим заявлением, которое Джохар нацарапал на лодке, в которой его нашли - «Правительство США убивает наших невинных граждан», предположительно имея в виду $y м м y .{ }^{51}$ Аль-Каида не только использует религиозную риторику, но так же имеет присущие политические цели, которые связаны с конкретной средой. Важно отметить, что эти политические цели были в интересах населения, на которое направлены усилия Аль-Каиды, за несколько десятилетий до формального появления Аль-Каиды.

Чтобы представить себе сцену действий, надо понять, что Аль-Каида воплощает идеологию, которая уже существовала в исламском мире в течение столетий. Усама бен Ладен артикулировал идеологию Аль-Каиды до нападений в сентябре 2001 года в нескольких заявлениях. Он заявил, что Соединенные Штаты, их союзники на Западе и конспиративные режимы на Ближнем Востоке совершают «крестоносный поход» против мммыl. $^{52}$ Бен Ладен призвал мусульман по всему миру вести «оборонительный джихад» против Соединенных Штатов и их союзников, так как Соединенные Штаты являются оккупантом святой земли Саудовской Аравии. ${ }^{53}$ Эту войну между Западом и исламским миром надо вести для создания заново «священного халифата», который будет управляться исламским законом и исламскими политиками. ${ }^{54}$ Эта смесь религии и политики не нова для ислама. Действительно, отцом идеологии Аль-Каиды является Шейх ибн Таймия, теолог тринадцатого века, который отказывался принять «подчинение религии политике» для тех, кто исповедует ислам. ${ }^{55}$ Незначительное меньшинство людей согласны с этой идеологией; однако есть достаточное количество людей, которые приписывают исламистским идеологическим положениям Аль-Каиды тот факт, что этот подход служит сильным инструментом для вербовки сторонников этой группы с момента ее создания. Идеология Аль-Каиды, как мы знаем, часто основывается на религиозной риторике и использует ислам как оправдание своих насильственных

50 Reitman, "Jahar's World."

51 Denise Lavoie and Tom Hays, "Dzhokhar Tsarnaev, Boston Bombing Suspect, Was Influenced By Internet: Indictment," The Huffington Post (28 June 2013); доступно на www.huffingtonpost.com/2013/06/28/dzohkhar-tsarnaev-internet-indictment_n_3515432.html.

52 Christopher M. Blanchard, Al Qaeda: Statements and Evolving Ideology, CRS Report for Congress RL32759 (Washington, D.C.: Congressional Research Service, 9 July 2007), 3; доступно на www.fas.org/sgp/crs/terror/RL32759.pdf.

53 Там же.

54 Там же.

55 Turner, "From Cottage Industry to International Organization," 549. 
действий. Теоретики часто не принимают Аль-Каиду как чисто крайнее религиозное движение, тогда как другие считают, что в исламе есть насильственное течение, которое Аль-Каида канализирует и усиливает, чтобы оно стало проводником ненависти. Однако эти теоретики не видят, что Аль-Каида является смесью политического и религиозного движения. Хотя риторика Аль-Каиды может быть и религиозна, она имеет политическую идеологию и преследует политические цели. В конце концов, в своей сущности «терроризм есть форма политического насилия». 56

Ричард Деветак утверждает, что многие из террористических атак, в том числе и совершенные Аль-Каидой, имеют «гиперрелигиозную мотивацию». 57 Эти акты могут быть упакованы в религиозную риторику, но в своей сердцевине они остаются политическими. Аль-Каида пытается изменить политический ландшафт по всему миру, заменив общественный договор Гоббса между управляющими и управляемыми на договор между Богом и его народом на основе законов Шариата. ${ }^{58}$ Аль-Каида сконструировала нарратив, который погружен в религию и использует религиозную мотивацию, чтобы осуществлять политические акции, ставя ударение на определенные моменты истории ислама и на определенные части Корана. Аль-Каида говорит своим последователям и тем, кого она надеется завербовать, что необходима «жестокая борьба, чтобы изменить мир». ${ }^{59}$ Та же риторика была обрисованы выше при обсуждении способов вербовки, которыми пользуются неонацисткие организации скинхедов. Белые супремасисты в Соединенных Штатах пытаются создать в Северо-Западных Соединенных Штатах «арийское отечество», а Аль-Каида надеется восстановить исламский халифат. ${ }^{60}$ Борьба Аль-Каиды является религиозной обязанностью, но нет никакого сомнения, что она направлена на политический результат.

Марк Юргенсмейер, который говорит о «Космической войне» ${ }^{61}$ между исламом и Западом, описывает идеологию Аль-Каиды как «облаченную в религиозные одежды политику». ${ }^{6}$ Риторика Аль-Каиды может казаться апокалиптической, но она имеет свои корни в желании изменить существующее статус-кво. Как было упомянуто выше, это желание осуществить социальные изменения, когда чье-то сообщество несправедливо изолировано, атаковано или подавляется, предназначено оказывать влияние на людей, которые испытывают аномию в своей жизни. ${ }^{63}$ Понятно, что религиозно окрашенные политические цели Аль-Каиды находят резонанс у мусульман на Западе, которые думают, что ислам и их культура в течение

\footnotetext{
Devetak, "Violence, Order, and Terror," 232.

Там же.

Там же, 239.

Там же, 240.

60 Blazak, "White Boys to Terrorist Men," 994.

${ }^{61}$ Mark Juergensmeyer, Terror in the Mind of God: The Global Rise of Religious Violence, $3^{\text {rd }}$ ed. (Berkeley, CA: University of California Press, 2003).

62 Devetak, "Violence, Order, and Terror," 242.

63 Blazak, "White Boys to Terrorist Men."
} 
веков были объектом нападения. Аль-Каида использует эту риторику, чтобы взывать к тем людям, которые надеются вернуть свою собственную версию «статус-кво» - вернуть могущество исламского халифата после многих лет господства Запада на Ближнем Востоке. ${ }^{64}$

Чеченская идентичность братьев Царнаевых связана с борьбой этого региона против России как оккупирующей силы. Легко увидеть, как эти молодые люди экстраполировали связь между русским господством над преобладающе мусульманскими провинциями Чечня и Дагестан и «империалистической» программой Соединенных Штатов борьбы против мусульман по всему свету. Тамерлан погрузился в этот образ мышления во время своего пребывания в Дагестане, когда он посещал местные салафистские мечети вместе со своим двоюродным братом, Магомедом Карташовым, известным исламистом из столицы Дагестана Махачкалы. ${ }^{65}$ Группа Карташова «Союз справедливых» публично отрицает насилие, но говорит со злобой о интервенционизме США, в частности на Ближнем Востоке, и об экспорте либерального мышления. ${ }^{66}$ Хотя Тамерлан так же хорошо разбирался в дискурсе крайнего правого экстремизма, эта физическая, идеологическая индоктринация в духе салафистского джихадисткого мышления дала ему ощущение принадлежности к умме, связи к которой он отчаянно стремился, чтобы успокоить свою одинокую душу.

Усама бен Ладен и Айман аль-Завахири добились успеха в распространении послания, что мировое сообщество мусульман имеет право на ведение «оборонительного джихада» против Соединенных Штатов и их союзников, которые оккупировали Ближний Восток. ${ }^{67}$ Эти лидеры использовали аналогию между крестовыми походами и борьбой современности в попытке увеличить историческую и идеологическую правдоподобность своих утверждений. Действительно, политическая идеология Аль-Каиды и террористическая тактика, которую она использует, чтобы ее пропагандировать, связаны со «столетиями древней борьбы за господство в исламском мире». ${ }^{68}$ Придерживаясь исламистского мировоззрения, согласно которому ислам должен быть моделью для политического, экономического и общественного порядка, лидеры Аль-Каиды по сути дела выдвигают фундаментальный политический аргумент о характере будущего государства, которое они надеются создать путем джихада.

64 “Bin Laden's Fatwa,” PBS News Hour (23 August 1996); доступно на www.pbs.org/ newshour/updates/military/july-dec96/fatwa_1996.html.

65 Simon Shuster, "Exclusive: Dagestani Relative of Tamerlan Tsarnaev Is a Prominent Islamist," Time Magazine (8 May 2013); доступно на world.time.com/2013/05/08/exclusive-cousinwho-became-close-to-tamerlan-tsarnaev-in-dagestan-is-a-prominent-islamist/.

66 Там же.

67 Michael Scheuer, Through Our Enemies' Eyes: Osama Bin Laden, Radical Islam, and the Future of America (Washington, D.C.: Potomac, 2006), 54.

68 Turner, "From Cottage Industry to International Organization," 542. 


\section{Интернет и индоктринация, осуществляемая Аль-Каидой}

В августе 1996 года Усама бен Ладен выпустил фетву, озаглавленную «Объявление войны против американцев, оккупировавших землю двух святых мест». ${ }^{69}$ Фетва является обязывающим религиозным эдиктом, издаваемым фигурой религиозной власти в исламе. Однако, поскольку в исламе не существует иерархической структуры, многие лица считают, что они имеют право издавать фетвы. В своем заявлении бен Ладен изложил видение, что «люди ислама страдают от агрессии» США и «Ционистко-крестоносного альянса». ${ }^{70}$ Становится ясно, что бен Ладен пытался ответить на серию унижений, которым подвергся исламский мир после распада Оттоманской империи. ${ }^{71}$ Выше я уже отметила, что белые супремасисты часто вербуют людей в свои ряды, утверждая, что их положение в обществе находится под угрозой и его надо защитить. Схожим образом, Аль-Каида и ее филиалы создают нарратив, умма насильственно подавляется, и чтобы исправить это зло, оккупированные земли исламского халифата надо освободить. ${ }^{72}$ Все чаще она использует онлайн форумы для распространения этого послания.

Интернет является исключительно важным инструментом для идеологической индоктринации рекрутов Аль-Каиды на Западе. Многие рекруты подвергаются идеологической вербовке путем персонального взаимодействия. Однако, Аль-Каида успела создать Интернет конгломерат, который легко доступен для тысяч людей на Западе. ${ }^{73}$ Аль-Каида создала несколько хорошо известных Интернет чатов, в том числе «Аль-Шумук» и «Аль-Фида», ${ }^{74}$ которые работают как «игровая» система. ${ }^{75}$ Такая система дает людям стимулы оставаться в чат-руме, давая им очки и награды за их посты; эта система также поощряет дальнейшую радикализацию. Согласно Джаретту Бракман и Аликсу Левин из журнала Форин полиси, «Большинство граждан Запада, следующих радикальной интерпретации ислама, которые были арестованы по обвинению в терроризме, или были активными участниками форумов хардлайнеров, или у них были экстремистские материалы, скачан-

69 "Bin Laden's Fatwa."

Там же.

Там же.

Там же.

73 Brian M. Jenkins, “Is Al Qaeda's Internet Strategy Working?” RAND Corporation, Testimony presented before the U.S. House of Representatives Homeland Security Committee, Subcommittee on Counterterrorism and Intelligence (6 December 2011); доступно на www.rand.org/ content/dam/rand/pubs/testimonies/2011/RAND_CT371.pdf.

74 Ellen Nakashima and Joby Warrick, “Al Qaeda's Online Forums Go Dark for Extended Period," Washington Post (2 April 2012); доступно на http://www.washingtonpost.com/world/ national-security/al-qaedas-online-forums-go-dark-for-extended-period/2012/04/02/gIQAfd4x qS_ story.html.

75 Jarrett Brachman and Alex Levine, "The World of Holy Warcraft," Foreign Policy (13 April 2011); доступно на www.foreignpolicy.com/articles/2011/04/13/the_world_of_holy_warcraft. 
ные из сети». ${ }^{76}$ Наиболее наглядным примером идеологической интернет радикализации, индоктринации и индивидуального использования Интернета для радикализации других является случай Захарии Чессера.

\section{Случай Захарии Чессера}

Выросший в провинциальной Виргинии, Захария Чессер обратился в ислам в 2008 году, летом, перед поступлением в колледж в результате переживания, связанного с футбольной командой. Члены Хизб ут-Тахрир, радикальной узбекской исламистской политической организации, спонсировали футбольную команду. ${ }^{77}$ Этот первый опыт, связанный с исламом, подчеркивает важность вербовки через институции, которая будет обсуждаться в следующем разделе этой работы. Идеологическая вербовка и радикализация Чессера исключительно интересны из-за скорости, с которой происходил этот процесс. Менее чем за шесть месяцев его взгляды стали настолько строгими, что он начал искать дальнейшую идеологическую поддержку своей радикальной точки зрения. Чессер признает, что он обратился к Интернету потому, что «это просто наиболее динамическая и удобная форма медиа, которая существует». ${ }^{78}$ Случай Чессера наиболее информативен потому, что он оставался честным при даче показаний. Его собственное заявление говорит об идеологическом притяжении, которое он почувствовал при формировании отношений с радикальными исламистами через Интернет. Он сказал: «Мусульманин, который искренне знакомится с их религией, поймет, что применение исламского закона обязательно [sic], что голосование есть сомнительная вещь, что джихад становится обязательным в случае вторжения не-мусульман в мусульманские земли. Вот, что я нашел, и это по существу найдет каждый ... Тот, кто начинает изучать, с какого-то момента неизбежно начинает рассматривать джихад как жизнеспособную и желательную концепцию». ${ }^{79}$ Заявление Чессера показывает, как после того как основные положения идеологии Аль-Каиды найдут почву, люди начинают принимать участие в джихаде дома или за границей, завершая процесс радикализации.

Возможно, наиболее важным результатом радикализации Чессера является его приверженность учению Анвара аль-Авлаки и его корреспонденция с этим идеологическим лидером, имевшая место до ареста Чессера в Уганде в 2010 году. В смысле структурного рекрутирования, аль-Авлаки был важным членом Аль-Каиды на Арабском Полуострове (АКАП) до его смерти в 2012 году. В последнее

\footnotetext{
Там же.

77 "Zachary Chesser: A Case Study in Online Islamist Radicalization and Its Meaning for the Threat of Homegrown Terrorism," Report to the U.S. Senate Homeland Security and Governmental Affairs Committee (February 2012), 5; доступно на www.hsgac.senate.gov/ $\mathrm{imo} / \mathrm{media} / \mathrm{doc} / \mathrm{CHESSER} \% 20 \mathrm{FINAL} \% 20 \mathrm{REPORT} \% 281 \% 29 . \mathrm{pdf}$.

78 Zachary Chesser, Letter to U.S. Senate Homeland Security and Governmental Affairs Committee, 6 September 2011; доступно там же. Там же.
}

79 
время АКАП стала наиболее активным и опасным отделением Аль-Каиды. ${ }^{80}$ Однако, идеологические проповеди и писания аль-Авлаки действовали как важный фактор при вербовке людей на Западе. Кроме того, аль-Авлаки свободно владел английским языком и был гражданином США, говорил спокойно, но проповедовал с убедительностью, которая привлекала тысячи онлайн последователей, которым нравились его заявления, являющиеся религиозным оправданием терроризма. ${ }^{81}$ Аль-Авлаки затрагивал струну в душе многих людей благодаря своему прошлому в Америке, видимому благочестию и религиозной компетентности, а также умелому использованию Интернета в качестве инструмента для вербовки последователей. Джохар Царнаев признался, что он и его брат следили онлайн за проповедями аль-Авлаки. ${ }^{82}$

Чессер стал последователем аль-Авлаки примерно три месяца после его обращения в ислам. Нет сомнения, что Анвар аль-Авлаки дал Чессеру идеологическое оправдание для его решения обеспечить материальную поддержку для исламистских боевиков Аль-Шабаба и поехать в Сомали для попытки включиться в филиал Аль-Каиды. Описывая свое желание найти практическое применение своих идеологических убеждений, Чессер сказал: «Я решил, что Аль-Шабаб соответствует шаблону [sic]. Аль-Авлаки просто направил для меня радар на аль-Шабаб».83 Чессер обменялся электронными письмами с аль-Авлаки относительно его решения поехать за границу, и аль-Авлаки поощрил его ехать, если он думает, что это было бы «полезно». ${ }^{84}$ Чессеру следовало заняться идеологической вербовкой других перед попыткой поехать в Сомали. После того как он был завербован, Чессер в свою очередь пытался завербовать других путем использования Интернета и идеологических заявлений. Эта стратегия использовать неофитов как «идеологических пехотинцев» является важным элементом целостной политической стратегии АльКаиды.

\section{По ту сторону Интернета}

Чессер понимал важность идеологической индоктринации для обеспечения достаточного количества рекрутов для Аль-Каиды в будущем. Чессер создал Революиионный мусульманин, ${ }^{85}$ сайт для радикальных западных мусульман (особенно для

80 "CIA Chief Says AQAP Most Dangerous in "Global Jihad'," Xinhua News (14 September 2011); доступно на http://news.xinhuanet.com/english2010/world/2011-09/14/c_13113675 4.htm.

81 "Zachary Chesser: A Case Study in Online Islamist Radicalization and Its Meaning for the Threat of Homegrown Terrorism," 10.

82 Daniel Klaidman, "Exclusive: The Awlaki/Tsarnaev Connection," The Daily Beast (26 April 2013); доступно на www.thedailybeast.com/articles/2013/04/26/the-awlaki-connection.html.

83 Zachary Chesser, Letter to U.S. Senate Homeland Security and Governmental Affairs Committee, 4 October 2011.

84 Там же.

85 Christopher Anzalone, "Zachary Chesser: An American, Grassroots Jihadist Strategist on Raising the Next Generation of Al Qaeda Supporters," Perspectives on Terrorism 4:5 (2010): 22. 
тех, кто живет в Соединенных Штатах), а также он был автором Муджахедблога, который был предназначен для вербовки мусульман, живущих на Западе. ${ }^{86}$ Чессер понимал важность участия и победы в «войне идей» против Запада для успеха Аль-Каиды. ${ }^{87}$ По этой причине он пытался стать плодовитым онлайн джихадистом, как и Самир Хан (из Инспаер) и аль-Авлаки, и создал серию, названную Контр-контр-терроризм. ${ }^{88}$ Последнее эссе Чессера перед его арестом называлось «Выращивание Аль-Каиды: взгляд на долгосрочные обязательства джихадистского движения». ${ }^{89}$ Чессер обсуждал разные мероприятия по созданию идеологических посланий, которые Аль-Каида должна предпринять, чтобы выжить, в том числе и «нормализацию» идеи джихада. ${ }^{90}$ Он также говорил о развитии и поддержке большей роли женщин в «воспитании» детей так, чтобы они становились членами Аль-Каиды. ${ }^{91}$

Чессер дошел до того, чтобы настаивать, чтобы члены Аль-Каиды подражали «внутренней пропагандистской машине», которая существует в Соединенных Штатах, так как он считал, что Соединенные Штаты создали самые сильные идеологические связи между отдельным человеком и нацией. ${ }^{92}$ Он предлагал, чтобы Аль-Каида должна зеркальным образом повторить их послание, чтобы вызвать «слепой патриотизм», который испытывают граждане Соединенных Штатов, когда собираются толпой под звуки «пустых понятий и напыщенных слов» своих политиков. ${ }^{93}$ Чессер считал, что взращивание этого чувства патриотизма в детях создаст больше джихадистов в будущем. Несмотря на онлайн успех, Чессер не был удовлетворен долей пропагандного онлайн вербовщика. Он считал, что поездка с целью принять участие в джихад является религиозным обязательством и важной частью идеологии Аль-Каиды. ${ }^{94}$

10 июля 2010 года Чессер попытался сесть на самолет, направляющийся в Уганду вместе со своим маленьким сыном, с надеждой попасть в Сомали, чтобы присоединиться к Аль-Шабаб. ${ }^{95}$ Как указывает Марта Креншоу, многие рекруты вдохновлены идеологией Аль-Каиды, но это нормально, пока они не поедут за

86 "Zachary Chesser: A Case Study in Online Islamist Radicalization and Its Meaning for the Threat of Homegrown Terrorism," 16.

87 Там же.

88 Там же.

89 Anzalone, "Zachary Chesser," 22.

90 Там же, 23.

91 Там же, 25.

92 Там же.

93 Там же.

94 Там же, 29.

95 "Zachary Chesser: A Case Study in Online Islamist Radicalization and Its Meaning for the Threat of Homegrown Terrorism," 19. 
границу и не начнут участвовать в операциях. ${ }^{96}$ Чессеру не разрешили сесть в самолет и его арестовали 21 июля за попытку предоставить материальную помощь Аль-Шабаб. ${ }^{97}$ Чессер верил, что его религиозной обязанностью в исламе было поехать за границу, чтобы воевать, но к его разочарованию, до его ареста ему дважды запрещали поехать в Сомали. ${ }^{98}$ Он признался виновным по всем предъявленным обвинениям и был приговорен к двадцати пяти годам заключения в федеральной тюрьме США. ${ }^{99}$

Ни один из элементов вербовки Захарии Чессера Аль-Каидой не дает основание считать, что существует в какой бы то ни было степени терроризм «одиноких волков». Чессер получил свой первый опыт с салафистским джихадизмом в социальной институции, в футбольной команде, и обратился в ислам вскоре после этого. Его женитьба на женщине, которую он встретил в Интернет форумах АльКаиды, дает основание считать, что идеологические отношения, сформированные в Интернете, могут породить отношения в реальном мире. ${ }^{100}$ И последнее, Чессер хотел поехать в Сомали и принять участие в джихаде, что доказывает, что желание быть частью сообщества является фокусом вербовки. Хотя Чессер действовал в одиночку, за исключением помощи жены, у него были множество связей как в Интернете, так и в международном сообществе, что опровергает любые утверждения теоретиков, что он был «волком-одиночкой».

Братья Царнаевы тоже не действовали в одиночку: радикализации Тамерлана способствовали шесть месяцев, проведенных в Дагестане, и братья рассчитывали на свои семейные связи. Хотя неизвестно точно, как братья были привлечены к оперативной работе, похоже, что Джохар просто следовал за радикализацией брата. И снова, нельзя недооценивать важность связей при попадании под влияние радикальной идеологии. Процесс радикализации не происходит в вакууме, что подвергает сомнению нарратив о терроризме «волков-одиночек».

Шестимесячное пребывание Тамерлана в Дагестане, несомненно, углубило его радикализацию, так как он встречался с известными салафистами и свободно разговаривал о джихаде. ${ }^{101}$ Его радикализация, однако, началась, когда его мать попросила его стать более религиозным, чтобы отвратить его от употребления алкоголя и наркотиков. Тамерлан настолько погрузился в религию, что начал упрекать своих родных и даже поощрял свою мать носить хиджаб. Вместе они настолько

96 Martha Crenshaw, Statement Before the Subcommittee on Intelligence, Information Sharing, and Terrorism Risk Assessment, Committee on Homeland Security, U.S. House of Representatives, "Hearing on Reassessing the Evolving al-Qa'ida Threat to the Homeland" (19 November 2009), 4; доступно на http://iis-db.stanford.edu/pubs/22749/MCrenshaw.pdf.

97 Там же.

98 Anzalone, "Zachary Chesser," 28.

99 "Zachary Chesser: A Case Study in Online Islamist Radicalization and Its Meaning for the Threat of Homegrown Terrorism," 25.

100 "Wife of Virginia Man who Threatened South Park Pleads Guilty," Anti-Defamation League (9 November 2010); доступно на www.adl.org/main_Terrorism/nzabanita_chesser.htm.

${ }^{101}$ Shuster, "Exclusive: Dagestani Relative of Tamerlan Tsarnaev Is a Prominent Islamist." 
окунулись в религию, что их семья начала распадаться, так как его отец не мог понять, почему изменилось поведение сына. ${ }^{102}$ Тамерлан не мог вписаться в общество местной мечети в 2009 году, где он взорвался по поводу проповеди, восхваляющей Мартина Лютера Кинга. Те, кто присутствовали на службе в тот день, были шокированы его вспышкой. Его предупредили, что если это случится еще ра3, ему запретят посещать мечеть. ${ }^{103}$

Встречи Тамерлана в Дагестане подтолкнули его к радикализации, но те, с кем он был в контакте, отсоветовали его включаться в борьбу в Чечне. Они предложили ему вернуться домой. ${ }^{104}$ Снова отвергнутый, вооруженный усилившейся за время его пребывания в Дагестане неприязнью к Соединенным Штатам за их интервенцию на Ближнем Востоке, Тамерлан и его брат начали планировать взрывы. Джохар, упорно пытающийся преуспевать в школе и попадающий во все большую изоляцию, вцепился в единственную оставшуюся ему связь. Источником его радикализации был его брат.

Вместе Царнаевы поглощали салафисткие джихадисткие пропагандные видео из Интернета, в том числе и предсказания о мировой священной войне для возрождения исламского халифата. ${ }^{105}$ Они открыли существование Инсnаер, пропагандного журнала Аль-Каиды на Арабском Полуострове (АКАП). На его страницах братья нашли инструкции, как сделать бомбу из скороварки в статье под названием «Как сделать бомбу на кухне вашей мамы». ${ }^{106}$ И что более важно, Инcnaep часто поощряет жителей Запада, которые хотят участвовать в войнах за границей, считать себя «джихадистом соседом» и совершать нападения в своей собственной стране. ${ }^{107} \mathrm{~B}$ известном видео Адам Гахдан напоминает симпатизантам в США, что страна «завалена оружием», которое «легко достать». Это видео заканчивается зловещим вопросом «Чего вы еще ждете?». ${ }^{108}$ Пропаганда такого типа дополнительно подтолкнула братьев на путь насилия.

Быстрая радикализация Захарии Чессер через идеологические отношения и вербовку, которая началась в футбольной команде, но была усилена на Интернет форумах Аль-Каиды, является важным примером для изучения в Соединенных Штатах. Чессер понимал важность идеологических оснований вербовочной машины Аль-Каиды и попытался усилить эффективность и охват этих вербовочных

${ }^{102}$ Cullison, Sonne, George-Cosh, and Troianovski, “Turn to Religion Split Suspects' Home.”

103 Там же.

${ }^{104}$ Shuster, "Exclusive: Dagestani Relative of Tamerlan Tsarnaev Is a Prominent Islamist."

${ }^{105}$ Lavoie and Hays, "Dzhokhar Tsarnaev, Boston Bombing Suspect, Was Influenced By Internet."

${ }^{106}$ Eli Lake, "Al Qaeda's Recipe for Pressure-Cooker Bombs," The Daily Beast (16 April 2013); доступно на http://www.thedailybeast.com/articles/2013/04/16/al-qaeda-s-recipe-for-pressurecooker-bombs.html.

${ }^{107}$ Inspire Magazine, Issue 10 (March 2013).

${ }^{108}$ Sam Stein, "White House Taking 'Seriously' Al Qaeda's Eying of America's Gun Show Loophole," The Huffington Post (7 June 2011); доступно на www.huffingtonpost.com/2011/06/07/ white-house-taking-seriously-al-qaeda-gun-show_n_872413.html. 
мероприятий своими собственными текстами. Его единственной ошибкой было то, что он стал настолько производительным в постах и в желании рекрутировать других для дела джихадизма, что обратил внимание властей на себя, что привело к его аресту. Однако, благодаря усилиям таких пропагандистов как Чессер, - и печально известного Анвара аль-Авлаки и его йеменской когорты, которые продолжают публикацию журнала Инсnаер, - многие недовольные молодые мужчины, похожие на братьев Царнаевых, подвергаются риску стать жертвой радикальных взглядов на мир Аль-Каиды.

Сами Царнаевы, хотя у них не было связей ни с какой ветвью Аль-Каиды, поддались этой идеологии и совершили ужасный акт насилия, который привел к смерти трех молодых людей и ранению нескольких сот жителей в прекрасный день в Бостоне. Успех идеологической вербовки и пропаганды Аль-Каиды обеспечил братьям Царнаевым главную роль в последнем номере журнала Инспаер, вышедшем в мае 2013 года. ${ }^{109}$ На первой странице журнала Аль-Каида заявила: «Американцы, вы должны понять это простое уравнение: если вы убиваете, и вас будут убивать. Вчера это был Багдад, сегодня это Бостон». Инсnаер заявляет, что «два великих брата», Тамерлан и Джохар, члены Аль-Каиды, хотя их связь с движением была чисто идеологической. Тамерлан изображен на небесной сцене, одетый в яркие одежды времен его боксерского периода и в авиаторских очках. Инcnaеp призывает всех «настоящих» западных мусульман следовать примеру братьев Царнаевых. Началось прославление Царнаевых на онлайн форумах и в чатрумах, где обсуждаются будущие заговоры и религиозные игры с очками и уровнями. ${ }^{110}$ Отчужденные люди будут находить удовлетворение в связях с этим сообществом, и цикл может начаться снова.

\section{Заключение}

Следующее заседание федерального суда по делу Джохара Царнаева состоится 23 сентября 2013 года. Ко времени написания этой работы он вознамеривается не признавать себя виновным ни по одному пункту обвинения. ${ }^{111}$ Независимо от исхода судебного дела, из радикализации Царнаевых можно сделать важные выводы, особенно из процесса радикализации Тамерлана. Тамерлан испытывал отсутствие норм и аномию в своей жизни настолько сильно, что открыто признал, что у него нет «ни одного американского друга». Это ощущение отсутствия корней, вызванное его трудным детством и неспособностью вписаться в какую бы то ни было социальную группу, способствовали тому, что он попал под влияние крайних правых экстремистов, белых супремасистов и салафистской джихадистской идеологии. Чувство цели и принадлежности к обществу, которые эти идеологии дают людям, находящимся в состоянии изолированности от обще-

\footnotetext{
${ }^{109}$ Inspire Magazine, Issue 11 (June 2013).

${ }^{110}$ Brachman and Levine, "The World of Holy Warcraft."

${ }^{111}$ Oppel and Bidgood, "Marathon Bombing Suspect, in First Court Appearance, Pleads Not Guilty."
} 
ства, являются сферой, которую надо исследовать ученым и специалистам по контртерроризму. Возможно, если ФБР сумело рассмотреть эти характеристики в Тамерлане, когда они допрашивали его летом 2011 года по просьбе российского правительства, его радикализацию можно было бы и предотвратить. ${ }^{112}$

Радикализации Тамерлана способствовали и отношения, которые он завязал в Дагестане, его привязанность к матери и его связь с братом Джохаром. Эти отношения подтолкнули братьев к дальнейшей радикализации. Их отношение к идеологии Аль-Каиды, а также их вера в то, что они защищают умму, подчеркивают значение установления социальных связей для процесса радикализации. Радикализация, независимо, осуществляется ли она по Интернету или лично, редко происходит в вакууме. Поэтому боязнь терроризма «волка-одиночки» сильно преувеличена. Наоборот, контртерроризм и органы правопорядка должны сосредоточиться на перехвате тех, кто испытывает аномию в своей жизни.

И последнее, нельзя преувеличить значение пропагандной машины Аль-Каиды для идеологической индоктринации и процесса вербовки последователей. Рассмотрением случая Захарии Чессера я показала, как отдельные люди могут подвергнуться радикализации только через онлайн сообщество. Чессер понимал важность онлайн вербовки, и Аль-Каида в курсе того, что одинокие молодые люди из групп риска легко попадают под влияние радикальной пропаганды, к которой есть легкий доступ в Интернете в виде проповедей и на страницах журнала Инспаер. Взрывы на Бостонском марафоне замкнули цикл этого нарратива. Братья Царнаевы, недовольные и одинокие, действовали в соответствии со своими насильственными убеждениями, порожденными журналом Инсnаер, а теперь они стали звездами майского номера журнала за 2013 год.

Так как Соединенные Штаты стараются остановить следующих западных экстремистов до того, как они начнут действовать, идеологическое развитие братьев Царнаевых, особенно Тамерлана, очень поучительно. Теоретики могут использовать бессмысленные клише типа «Аль-Каида 3.0», но по правде, такой тип радикализации очень типичен для Соединенных Штатов сейчас и был таким в течение десятилетий. ${ }^{13}$ В случае Тамерлана можно увидеть одинокого, неудовлетворенного молодого человека, который окунулся во всякие виды экстремисткой идеологии - с ним случилось то, что он культивировал персональные отношения, которые подтолкнули его к салафистскому джихадизму. Чтобы остановить следующего террориста, Соединенные Штаты должны понять, что и террористическое нападение на храм сикхов в Висконсине, совершенное белыми супремасистами в августе 2012, и бостонские взрывы в меньшей мере подтверждают преобладаю-

112 "2011 Request for Information on Tamerlan Tsarnaev from Foreign Government," Federal Bureau of Investigation National Press Release, 19 April 2013; доступно на http://www.fbi.gov/ news/pressrel/press-releases/2011-request-for-information-on-tamerlan-tsarnaev-from-foreigngovernment.

${ }^{113}$ Bruce Riedel, “Al Qaeda 3.0: Terrorism's Emergent New Power Bases,” The Daily Beast (3 December 2012); доступно на http://www.thedailybeast.com/articles/2012/12/03/al-qaeda-30-terrorism-s-emergent-new-power-bases.html. 


\section{THE QUARTERLY JOURNAL}

щий ныне нарратив, и в большей степени связаны с общественным положением этих террористов, которое привело их к радикальной идеологии. ${ }^{114}$ Это было бы фундаментальным изменением в нашем национальном подходе к контртерроризму, но это идея, чье время уже пришло.

${ }^{114}$ Brendan O’Brien, "Vigil at Wisconsin Sikh Temple Marks Anniversary of Shooting Attack," Reuters (6 August 2013); доступно на www.reuters.com/article/2013/08/06/us-usa-shootingsikh-idUSBRE97505320130806. 


\section{Литература}

2011 Request for Information on Tamerlan Tsarnaev from Foreign Government In National Press Release. Federal Bureau of Investigation, 2013.

Andersson, Hilary. Tamerlan Tsarnaev Had Right-Wing Extremist Literature. BBC News, 2013.

Anzalone, Christopher. "Zachary Chesser: An American, Grassroots Jihadist Strategist on Raising the Next Generation of Al Qaeda Supporters." Perspectives on Terrorism 4, no. 5 (2010): 22.

Bin Laden's Fatwa. PBS News Hour, 1996.

Blanchard, Christopher M.. Al Qaeda: Statements and Evolving Ideology In CRS Report for Congress. Washington, D.C.: Congressional Research Service, 2007.

Blazak, Randy. "White Boys to Terrorist Men: Target Recruitment of Nazi Skinheads." American Behavioral Scientist 44, no. 6 (2001): 982-1000.

Brachman, Jarrett, and Alex Levine. "The World of Holy Warcraft." Foreign Policy (2011).

Byman, Daniel L.. The Changing Nature of State Sponsorship of Terrorism In Analysis Paper. Saban Center for Middle East Policy at the Brookings Institution, 2008.

Chesser, Zachary. Letter to U.S. Senate Homeland Security and Governmental Affairs Committee., 2011.

CIA Chief Says AQAP Most Dangerous in 'Global Jihad'. Xinhua News, 2011.

Crenshaw, Martha. Hearing on Reassessing the Evolving al-Qa'ida Threat to the Homeland In Statement Before the Subcommittee on Intelligence, Information Sharing, and Terrorism Risk Assessment. Committee on Homeland Security, U.S. House of Representatives, 2009.

Cullen, Kevin. "New Details on Wild Shootout with Bomb Suspects in Watertown." Boston Globe (2013).

Cullison, Alan. "Boston Bombing Suspect Was Steeped in Conspiracies." The Wall Street Journal (2013).

Cullison, Paul Sonne Alan, David George-Cosh, and Anton Trioanovski. "Turn to Religion Split Suspects' Home." The Wall Street Journal (2013).

Elden, Stuart. "Territorial Integrity and the War on Terror." Environment and Planning 37 , no. 12 (2005).

Gerstein, Josh. Boston Bombing Suspects' Parents Granted Divorce in 2011. Politico.com, 2013. 
Jenkins, Brian M.. Is Al Qaeda's Internet Strategy Working? In Testimony presented before the U.S. House of Representatives Homeland Security Committee. RAND Corporation, Subcommittee on Counterterrorism and Intelligence, 2011.

Kirk, Chris, and Heather Brady. From Wrestling Captain to Terrorism Suspect: A Timeline of Dzhokhar Tsarnaev's Life. Slate.com, 2013.

Klaidman, Daniel. Exclusive: The Awlaki/Tsarnaev Connection. The Daily Beast, 2013.

Lake, Eli. "Al Qaeda's Recipe for Pressure-Cooker Bombs." The Daily Beast (2013).

Lavoie, Denise, and Tom Hays. Dzhokhar Tsarnaev, Boston Bombing Suspect, Was Influenced By Internet: Indictment. The Huffington Post, 2013.

Madden, Lance. "Boston Marathon Bombing Suspect No. 1 Tamerlan Tsarnaev Trained to Box for U.S." Forbes (2013).

Nakashima, Ellen, and Joby Warrick. "Al Qaeda's Online Forums Go Dark for Extended Period." Washington Post (2012).

Nakashima, Ellen, and Joby Warrick. "Al Qaeda's Online Forums Go Dark for Extended Period." Washington Post (2012).

O’Brien, Brendan. Vigil at Wisconsin Sikh Temple Marks Anniversary of Shooting Attack. Reuters, 2013.

Oppel, Richard, and Jess Bidgood. "Marathon Bombing Suspect, in First Court Appearance, Pleads Not Guilty." The New York Times (2013).

Orange, Richard. "Al Qaeda Rejects Anders Behring Breivik Comparison." The Telegraph (2012).

Reitman, Janeit. "Jahar's World." Rolling Stone 9 (2013).

Riedel, Bruce. "Al Qaeda 3.0: Terrorism's Emergent New Power Bases." The Daily Beast (2012).

Scheuer, Michael. Through Our Enemies' Eyes: Osama Bin Laden, Radical Islam, and the Future of America. Washington, D.C.: Potomac, 2006.

Shuster, Simon. "Exclusive: Dagestani Relative of Tamerlan Tsarnaev Is a Prominent Islamist." Time Magazine (2013).

Simon, Steven, and Daniel Benjamin. "America and New Terrorism." Survival 42, no. 1 (2000): 65 .

Simpson, Conor. "Meet the Man Who Supplied Tamerlan Tsarnaev with Right Wing Literature." The Atlantic Wire (2013).

Stein, Sam. "White House Taking 'Seriously' Al Qaeda's Eying Of America's Gun Show Loophole." The Huffington Post (2011). 
Terror in the Mind of God: The Global Rise of Religious Violence. 3rd ed. Berkeley: University of California Press, 2003.

Timothy McVeigh. CNN, 2001.

Turner, John. "From Cottage Industry to International Organisation: The Evolution of Salafi-Ji-hadism and the Emergence of the Al Qaeda Ideology." Terrorism and Political Violence 22 (2010): 542.

Weigel, David. "Tamerlan Tsarnaev, Dead Bombing Suspect: 'I Don't Have a Single American Friend'." Slate (2013).

Wife of Virginia Man who Threatened South Park Pleads Guilty. Anti-Defamation League, 2010.

Zachary Chesser: A Case Study in Online Islamist Radicalization and Its Meaning for the Threat of Homegrown Terrorism In Report to the U.S. Senate Homeland Security and Governmental Affairs Committee., 2012. 